\title{
How Family Firms Can Prevent (or Cool Down) Sibling Rivalries
}

\author{
Jonas Ruzek (Northeastern University) \\ Kimberly Eddleston (Northeastern University)
}

KEYWORDS: Management, Family Business, Conflict, Succession.

"Siblings are our partners and rivals, our first friends, and our first enemies." Dr. Erica Goldblatt Hyatt, Rutgers University

Stories abound about sibling rivalries that have harmed family businesses and the families behind them. For instance, Charles and David Koch were sued by their brothers, Bill and Fred, for allegedly duping the brothers into leaving Koch Industries (McDowell, 2020). Mukes and Anil Ambani had a long, bitter power struggle at Reliance Industries after their father, the organization's founder, died without a will (Badkar, 2011). Harrison and Wallace McCain, co-founders of McCain Foods, sparred over control of the business; their public battle continued until Wallace was forced out of the business in 1994 (Kiesnoski \& Parton, 2014). Famous wine maker Robert Mondavi was known for pitting his two sons against one another, creating an intense sibling rivalry that hurt both the business and the family (Howe, 2005).

Although tragic stories like these are often detailed in the popular press and serve as inspiration for television series like HBO's Succession, many siblings manage to lead their family businesses together in a productive, collaborative way. To better understand why some siblings are able to work so well together in their family's business, we sought the advice of acclaimed Northeastern University professor of applied psychology, Laurie Kramer, whose research focuses on the development of functional sibling relationships. Additionally, we interviewed several family business leaders who have managed to work incredibly well with their siblings or have taken steps to strengthen family relationships when the sibling partnership was strained in the business.

\section{Healthy Relationships Start Early}

Experts say that in order to prevent fallouts between siblings that hurt the family and the business, parents should start teaching their children relationship management skills as early as possible. Unlike other relationships in life, we do not choose our siblings, which makes for a unique dynamic. "Brothers and sisters can withstand far more negativity and behavior than our friends or co-workers," says Dr. Kramer. Thus, when siblings learn how to relate positively to one another, and to manage conflict effectively, they not only benefit from healthy, supportive sibling relationships but also learn to develop productive relationships throughout their lives.

First and foremost, Dr. Kramer emphasizes the importance of establishing healthy sibling relationships early on. "Parents should be thinking about this years in advance - well before they ask their children to enter the family business," she says.

Starting at a young age, children need to learn conflict resolution, cooperation, and open communication. "If parents can help their children to find words to talk about their complex reactions and feelings, it can set them up for supportive sibling relationships throughout life," Dr. Kramer says.

Sibling relationships serve as an early training ground to learn compromise, collaboration, and empathy for others. Since children mature emotionally through early interactions with their siblings, steering those dialogues in the right direction is critical for preventing harmful spats later in life. "Sibling relationships are often an effective context for developing an emotion vocabulary and expanding one's repertoire of emotional experiences....and learning to control and regulate one's expression of emotions" (Kramer (2014): 160-161). Kramer therefore recommends that parents should be mindful of the role they play-and the opportunities they
Copyright @ 2021 The Authors. Entrepreneur \& Innovation Exchange is published at EIX.org. This is an open access article under the terms of the Creative Commons Attribution-NoDerivs License, which permits use and distribution in any medium, provided the original work is properly cited and no modifications or adaptations are made. View EIX.org Authorship Terms at https://eix.org/terms
FamilyBusiness 
have-to foster positive sibling relationships among their children. (See Kramer, Conger, Rogers, \& Ravindran (2019) for an in-depth overview).

Family business researchers also recognize the important role parents play in shaping sibling relationships (e.g., Avloniti, latridou, Kaloupsis \& Vozikis, 2013; Eddleston \& Kidwell, 2012). When parents avoid comparing siblings to each other or treating children differently, the children are less likely to compete for parental affection and attention, and in turn, are better able to negotiate their roles in the family business and work effectively together. In contrast, when sibling rivalries transfer to a family business, it makes the succession process thornier, since each sibling fights for control and strives to out-compete the other. Extreme cases of sibling rivalry can lead to a complete failure of succession and even the eventual dissolution of the family firm (Avloniti et al, 2013). This is exactly what happened in the case of the Rosen family's retail liquor business in Chicago, where intense conflict between two brothers eventually led to the business's sale to outsiders (Clifford, 2007). Fortunately, a playbook of strategies can help siblings and parents alike tackle — and even prevent — sibling rivalries.

A good example of two sibling who have managed to work well together as they have grown their business is Antonietta DiLemme and Elisa Zullo. For 16 years, these sisters have co-owned Ristorante Molise, an authentic Italian eatery, in Amesbury, Massachusetts. Their restaurant has become a haven in the community, well known for its high-quality food and friendly service.

When asked about their relationship, DiLemme and Zullo acknowledged how siblings are often stereotyped for quarrelling. However, the sisters pointed out that they rarely fight. And when they do, DiLemme says, it's because the elder is taking on too many projects around the restaurant, at least in Zullo's eyes. "Our arguments are usually because we care about each other more than anything else," DiLemme says.

How can other business-owning families help to create healthy sibling partnerships? Experts who study sibling relationships and family business dynamics offer three key pieces of advice: learn conflict resolution strategies, assign roles based on merit, and give children a choice on whether to join the family business.

\section{Learn Conflict Resolution}

\section{Strategies}

Dr. Kramer has long counseled parents, teaching them how to guide their children's arguments to be constructive interactions, rather than destructive ones. By approaching arguments as constructive interactions, she says, parents can show their children that disagreements are fixable dilemmas. "Conflicts are really just problems. And the good thing about problems is that they have solutions," Dr. Kramer says. As a result, siblings who learn to resolve conflicts at a young age approach disagreements in a healthier manner throughout their lives; and they can use their conflict management abilities not only with their siblings, but with others as well (Kramer \& Kowal, 2005).

Yet, Dr. Kramer cautions that staying too involved in sibling conflicts as children mature can make them overly dependent on their parents' intervention. "Parents need to progressively lessen their involvement in their children's conflicts so that the siblings themselves are able to develop the skills to manage difficult interpersonal situations on their own."

Later, when siblings are working at their family's business together, it becomes important to distinguish between "emotional" conflicts and "strategic" conflicts, according to Fowler and Edquist (2004). Emotional conflicts represent a personal feud and should not be dealt with using company processes. Such emotional conflicts, which typically involve animosity and relationship discord, can be devastating to family business functioning and performance (Kellermanns \& Eddleston, 2004). Siblings with intense emotional conflicts have likely never learned to effectively manage disagreements, and instead, their relationship is characterized by intense power struggles and competition. In a family business setting, this often causes a negative spiral of dysfunction that leaves a path of destruction behind them, including high employee turnover, lawsuits, and ugly public battles in the press. A sad example was the public battle between the Berkowitz brothers of Legal Seafoods.

In contrast, strategic conflicts denote a disagreement about business strategy, goals and tactics, and consequently should be resolved professionally. In fact, a moderate degree of task conflict (i.e., disagreements about what strategies and business tasks to pursue) and process conflict (i.e., disagreements about how work should be performed and by whom) is often necessary to ward off stagnation and maintain a family 
business's competitive edge (Kellermanns \& Eddleston, 2004). Accordingly, family businesses should implement processes that encourage family members, as well as employees, to professionally air disagreements and work collaboratively to devise solutions. Siblings with effective conflict resolution skills are well poised to develop and lead such efforts.

Carl Beauregard, of Beauregard Equipment, a construction and agriculture equipment distributor with locations in Maine, New Hampshire, and Vermont, emphasizes the importance of creating channels for open communication to resolve conflicts. As a secondgeneration family member who was groomed alongside his three brothers to take over the family business, he is well aware of sibling rivalry. He explains, "Depending on the severity of the 'infraction,' sometimes it would blow by with the two brothers coming to terms. But when a conflict was more serious, the four of us would hold a brothers meeting and sort it out. The bottom line, we worked hard to not let issues fester and grow and were very conscious of not creating 'camps' within the organization with employees."

A useful tool to explore your family's conflict management style is outlined in this article by Ritch Sorenson: https://familybusiness.org/content/futurefamily-business-owners-can-learn-to-manag

\section{Assign Roles on Merit}

To help promote healthy working relationships between siblings, family businesses should be mindful of how organizational hierarchies and chains of command can intensify sibling rivalry. Experts often advise that siblings not be positioned above each-other in a company, for this dynamic can engender hostility (Federer, 2015). Working together adds complexity to a sibling relationship and thus, having one report to another often encourages power struggles. Rather, family business scholars suggest that whenever possible, siblings should have defined work roles that do not overlap (Avloniti et al., 2013). It is also advised that work roles both function and level - are based on merit and experience. "When siblings become frustrated and competitive, it may be because they have been assigned tasks that they are not well suited to." (Stanislaw, 2020).

Indeed, part of what makes DiLemme and Zullo's relationship work is a clear division of labor, according to DiLemme. "We understand that each of us has a job to do, so we don't fight.," she says. "I take care of the kitchen....and she takes care of the front of the house. So we have learned not to step on each other's feet." Both sisters also bring a bit of humor to their division of labor. Laughing, DiLemme points out: "My sister — she can't cook, so I had to cook. She can make the macaroni and cheese, OK?"

Carl Beauregard also emphasizes the importance of equality and merit to his family business's success especially in working with three brothers. He explains how none of the brothers was named to a higher position than any of the others. And all of them, starting in their teens, had to work their way up through the business, as opposed to being handed executive positions they were not ready for. "From early on, when my brothers and I were young and working part-time, we all had low-level tasks and jobs in the company," Beauregard adds, "As we became more proficient at tasks, we were moved around and cross-trained in departments - as we rose up the ranks to management levels."

And if equal status between siblings is, for whatever reason, unworkable in a family business, or if only one successor can be chosen, then parents should unambiguously communicate their reasoning to all of their children, Dr. Kramer says. "You can't just expect one of the children to understand a parent's decision about who they're leaving a particular role in the business to," she says, adding, "Everyone has a different perception of what's happening...And, on top of that, the research has shown that families hardly ever talk about their perceptions of differential treatment."

While Carl Beauregard credits his parents' management style with the relative harmony in the family firm, he also acknowledges some troubles the brothers experienced over the years as all four were charged with leading the business. The youngest brother often resisted initiatives that the other brothers hoped to pursue, causing friction at work and in their personal relationships. Eventually, the three elder siblings decided to buy the youngest brother out. As a result, "now that [my brother] is no longer a business partner, the three of us have a better personal relationship with him than ever before," Beauregard says. Another brother was also bought out in 2007. Recently, Carl Beauregard voluntarily retired from the business, leaving the family business in the capable hands of his brother. This lesson shared from Beauregard highlights our next piece of advice - giving 
them a choice - and specifically, how sibling relationships are sometimes stronger, and even healed, when the siblings do not feel pressured to work in the family business.

\section{Give Them a Choice}

Children often feel pressured to enter the family business. Some feel a sense of obligation to follow in their parents' footsteps; others may work in the business, despite having other career goals and desires, in order to maintain their place in the family (Kidwell, Eddleston, Cater, \& Kellermanns, 2013). As a result, children who feel forced to work in the family business are likely to take it out on their siblings, consciously or not.

"Parents should instill to their children the conviction that leaving the family business because working there is not part of a successor's dream is not something wrong" (Avloniti et al, 2013: 674). A family business owner we interviewed has internalized this advice. Caroline Jolliffe, the founder of two Thai restaurants in Newburyport, Massachusetts - Brown Sugar by the Sea and Joy Nest - believes that while children should be introduced to the family business, they should all have the opportunity to choose their own career paths. She encouraged each of her children -- aged 18, 20, and 22 -- to pursue a career that suits them rather than fight to succeed her.

Among her three children, the eldest, Tate, has helped out most at the restaurants over the years and seems to have an authentic interest in the business. "He happens to be a 'jack-of-all-trades' sort of person but also has an easy-going temperament - which is helpful in this business," Jolliffe says. And while she often jokes about succession with her oldest son, Jolliffe doesn't want to force Tate, a student at the University of Vermont, into a high-stress occupation he may not want.

"In a way, I don't want to wish this lifestyle on another generation, because it's pretty challenging," she says. "Because you give up your weekends and your nights, holidays, and all that." She stresses how important it is for Tate to have a passion for the business before she commits to handing it over to him.

Carl Beauregard also offers advice for parents: "If your child has a desire to enter the business, get the message instilled in them to earn the respect of fellow employees. One of the challenges is that you're the boss's son/daughter in employees' eyes, and the more you can address that in advance the more effective you'll be in the company. Working your way up through the ranks does a lot to dispel that 'boss's kid' notion." Additionally, he stresses how important it is for all children interested in the business to start at the bottom. Otherwise, if one child has it "easier" than the rest, sibling rivalry is inevitable.

\section{References}

Avloniti, A., latridou, A., Kaloupsis, I., \& Vozikis, G.S. (2013). Sibling rivalry: implications for

the family business succession process. IEMJ, 10(4), 661-678.

http://dx.doi.org/10.1007/s11365-013-0271-6.

Badkar, M. (2011, May 26). The Full Story of the Massive Feud Between the Billionaire

Ambani Brothers. Business Insider. https://www.businessinsider.com/ambanibrothers-feud-reliance-2011-05.

Clifford, S. (2007, August). Splitting heirs. Inc. Magazine, 29 (8), 102-110.

Eddleston, K.A. \& Kidwell, R.E. 2012. Parent-child relationships: Planting the seeds of deviant

behavior in the family firm. Entrepreneurship Theory \& Practice, 36(2): 369-386.

Federer, D. (2015, May 1). Avoid sibling rivalry in your family business. Business Observer FL.

https://www.businessobserverfl.com/article/avoidsibling-rivalry-your-family-business.

Fowler, D., \& Edquist, P. M. (2004, February 29). Sibling rivalry can destroy family business.

Milwaukee

Business

Journal.

https://www.bizjournals.com/milwaukee/stories/2004/03 /01/smallb5.html.

Kellermanns, F. W., \& Eddleston, K. A. (2004). Feuding families: When conflict does a family

firm good. Entrepreneurship theory and Practice, 28(3), 
209-228.

Kidwell, R.E., Eddleston, K.A., Cater, J.J. \& Kellermanns, F.W. 2013. How one bad family

member can undermine a family firm: Preventing the Fredo effect. Business Horizons, 56: 5-12.

Kiesnoski, K., \& Parton, C. (2014, October 10).Famous family business feuds. CNBC.

https://www.cnbc.com/2011/01/31/Famous-familybusiness-feuds.html.

Kramer, L. (2014). Learning Emotional Understanding and Emotion Regulation Through

Sibling Interaction. Early Education and Development, 25(2), 160-184.

http://dx.doi.org/10.1080/10409289.2014.838824.

Kramer, L., Conger, K. J., Rogers, C. R., \& Ravindran, N. (2019). Siblings. In B.H. Fiese (Ed.),

APA Handbook of Contemporary Family Psychology: Vol. 1. Foundations, Methods, and

Contemporary Issues Across the Lifespan. http://dx.doi.org/10.1037/0000099-029

Kramer, L., \& Kowal, A. K. (2005). Sibling relationship quality from birth to adolescence: the

enduring contributions of friends. Journal of Family Psychology, 19(4), 503. https://doi.org/10.1037/0893-3200.19.4.503

McDowell, E. (2020, April 2). 18 of the most epic sibling rivalries of all time. Business Insider.

https://www.businessinsider.com/famous-siblingrivalries-2014-6.

Sorenson, R. (2017). Future family business owners can learn to manage conflict.

FamilyBusiness.org.

https://familybusiness.org/content/future-family-

business-owners-can-learn-to-manag

Stanislaw, D. (2020, August 12). Keep Sibling Rivalry from Pulling Your Family Business
Apart. Stanislaw Consulting.

https://stanislawconsulting.com/how-to-keep-siblingrivalry-from-pulling-your-family-bu

(https://stanislawconsulting.com/how-to-keep-siblingrivalry-from-pulling-your-family-business-apart/)

siness-apart/(https://stanislawconsulting.com/how-to-ke ep-sibling-rivalry-from-pulling-your-family-businessapart/) . 